\title{
Natural selections: regularities observed in a case of untrained ad hoc academic interpreting
}

\author{
Seleções naturais: as regularidades \\ observadas num caso de interpretação \\ acadêmica ad hoc sem treinamento
}

William F. Hanes

\begin{abstract}
A case is presented in which a doctoral student in Scientific and Technological Education with no prior experience was asked to interpret a lecture by a foreign colleague with minimal preparation. The event was recorded and regularities in communication behavior were determined for both speaker and interpreter. Through these regularities in positioning, inferences were drawn regarding their assumptions about the interpretation act. Background information was obtained in an interview with the interpreter. Standing out among the findings was the high visibility of the interpreter, interposing herself both physically and by means of discourse between the audience and speaker, and this marginalization was tacitly accepted by the speaker, indicating a shared view of the interpreter as an acknowledged active participant and (re)shaper of the transmitted discourse.
\end{abstract}

Keywords: Consecutive interpreting; Competence development; Interpreter training; Ad hoc; Co-constructor.

Resumo: Um caso é apresentado no qual uma estudante de doutorado da área de Educação Científica e Tecnológica sem experiência prévia foi convidada com pouca antecedência para interpretar uma palestra de um colega estrangeiro. O evento foi 
HANES, W. F. - Natural selections: regularities observed in a case of untrained ad hoc academic interpreting

gravado, e regularidades no comportamento comunicacional foram determinadas para 0 palestrante e a intérprete. Através destas regularidades de posicionamento, inferências foram feitas com relação às suas suposições sobre 0 ato interpretativo. Informações extras foram obtidas em uma entrevista com a intérprete. Dentre as descobertas destaca-se a alta visibilidade da intérprete, que se interpõe fisicamente e através do discurso entre o público e o palestrante, marginalidade esta aceita tacitamente pelo último, indicando uma visão compartilhada do intérprete como um participante reconhecidamente ativo e (re)formulador do discurso transmitido.

Palavras-chave: Interpretação consecutiva; Desenvolvimento de competência; Treinamento de intérpretes; Ad hoc; Co-construtor.

\section{Introduction}

\subsection{An ad hoc world}

The many problems associated with ad hoc interpreting have received attention in areas such as healthcare and legal settings (PÖCHHACKER AND SHLESINGER 2007; Shlesinger 2008; Woloshin et al. 1995; KleinerT 2012, 2013), although the conditions generating such makeshift solutions continue to exist, if not predominate, in many fields outside international business, diplomacy and certain court systems, where funding guarantees access to professional personnel as well as proper equipment for simultaneous interpreting. However, it has been established by MARTINSEN (2002) that in community-based interpreting, employers do not necessarily prefer trained interpreters. Moreover, PIEKKARI et al. (2013) found that even when official translation departments are available in a multinational corporate context, a hierarchy of priorities leads employees to resort to nonofficial channels for a number of tasks involving multilingual communication. 
HANES, W. F. - Natural selections: regularities observed in a case of untrained ad hoc academic interpreting

Although immediacy and ephemerality are considered defining characteristics of interpretation (cf. PöCHHACKER 2010: 154), in ad hoc interactions, immediacy (in the sense of emergency) is the determinant principle; "getting the job done" and done "right now" overrides considerations of protocol, professionalism or a high degree of accuracy. The communication product is thus a means to an end: a disposable plastic cup, a hand-scrawled map from $A$ to $B$ and not something to be framed and critiqued. The interpreter in such cases is unburdened with consequences, ${ }^{1}$ provided the product, whether written or oral, is "good enough" to see the 'client', frequently a friend, family member or colleague, through the urgent situation.

However, not even the university is immune to ad hoc translating and interpreting solutions, which can be pursued despite (i.e. to the exclusion of) established interpreting, translation and foreign language departments (see LAMBERT AND ILIESCU 2014). Thus, it might be reasonable, as a point of departure for a study on ad hoc interpretation in academic settings, to work from a centerto-periphery model such that, on one level, less endowed universities and, on another, smaller-scale academic events/programming/projects would be more subject to this kind of solution.

\subsection{Why study ad hoc interpreting?}

Aside from its frequency ${ }^{2}$, if not favor, in the broadest, most commonplace interpreting domains (such as community interpreting), the candid, extra-(or pre-) professional character of ad hoc interpreting allows it to

\footnotetext{
1 Even more than the commitment and responsibility deficits, Anthony Pym ascribes to translators with respect to authorship (PYM 2010).

2 "Trained practitioners are still the exception to the rule in community-based interpreting, with most of it being performed by untrained, ad hoc bilinguals" (SHLESINGER 2007: 147-148)
} 
HANES, W. F. - Natural selections: regularities observed in a case of untrained ad hoc academic interpreting

be analyzed as an example of natural translation. In a longitudinal study of bilingual children cited by both TOURY (1986: 79) and PöCHHACKER (2010: 157), HARRIS AND SHERWOOD contend that translation/interpreting is an innate feature of bilingualism, already appearing in children from bilingual homes at less than two years of age (1978: 171), and that internalized standards of adequacy become more sophisticated as the child develops mentally and socially (ibid: 8). If it follows that translation/interpreting competence develops in parallel fashion in adolescent or adult acquirers of foreign languages, then perhaps a number of stages, irrespective of age or cognitive development, could be described, and a developmental model could be produced ${ }^{3}$. A step toward such a project would be to gather and analyze data by experience level. Within such a framework, the performance of uninitiated interpreters could be useful for revealing not only the internal logic of the language acquisition process but basic, 'naïve' assumptions about the interpreter's role as a social agent or cultural mediator.

\subsection{An ad hoc interpreting event}

In November 2013, a lecture in French on the public dissemination of science was given at the Universidade Federal de Santa Catarina (UFSC) in Florianópolis, Brazil, by a professor from the École Nationale Supérieure des Mines de Saint-Étienne. Held in a small classroom and consecutively interpreted by an UFSC postgraduate student, it was attended by less than 20 individuals, several of whom were professors from the Science and Technology Education department. Although the hour-long lecture, with an accompanying translated PowerPoint ${ }^{\circledR}$ presentation, could have been given in a large auditorium (given sufficient promotion and interest), the general surroundings gave it the

3 See Toury (1986) for further detail.

TradTerm, São Paulo, v. 23, Setembro/2014, p. 141-163

www. usp. br/tradterm

http:// www. revistas. usp. br/ tradterm/index 
HANES, W. F. - Natural selections: regularities observed in a case of untrained ad hoc academic interpreting

accessible feel of a class. Thus, clearly defining the interpreting genre of this event is already problematic. Such a setting could possibly qualify as what PÖCHHACKER (2010: 156) calls "conference interpreting in intra-social settings", but this point will not be belabored here since he goes on to advise that "the line between the two ends of the spectrum [i.e., conference vs. community interpreting] cannot always be clearly drawn" (ibid).

\subsubsection{A little background information}

The interpreter ("RL") is a doctoral candidate in Science and Technology Education who, besides earning an M.S. in Switzerland, was a former student of the speaker ("HJ") in France, so her linguistic competence for interpreting from French to Portuguese would seem to be a given, as well as her being well-versed in the general field, the speaker's discourse, and the specific projects under discussion. This was her first attempt at public interpretation, although she reported having formally translated one academic text. She was contacted by the speaker some months previously about interpreting an upcoming lecture at UFSC, but the only formal preparation was their sitting down for about 40 minutes on the eve of the lecture to go over the PowerPoint ${ }^{\circledR}$ (her first sight of it ${ }^{4}$ ), during which time she took some notes.

\section{Methods}

\subsection{Studying the event}

\footnotetext{
${ }_{4}^{4}$ The PowerPoint ${ }^{\circledR}$ presentation had been translated by the speaker's wife, who is a professor of French at UFSC.
} 

ad hoc academic interpreting

The lecture, including the subsequent question and answer period, was voice recorded and saved as an $\mathrm{mp} 3$ file for analysis. The interpreter was subsequently consulted for an interview (section 1.3.1). Since the interaction between the parties clearly demonstrated that the event consisted of more than the activity of the interpreter, but was rather more of a collaborative dyad of speaker and interpreter (or perhaps, more properly, a triad between them and the translated PowerPoint, or even the audience), it seemed best to broaden the analysis to include an examination of the speaker's interaction with the interpreter during the lecture.

\subsection{Analyzing the data}

As mentioned above, the $\mathrm{mp} 3$ of the event was the primary document used for analysis, although the importance of the translated PowerPoint was also evident and, thus, it was obtained from the speaker as supplementary information. Since I am not proficient in French, my observations will avoid sophisticated analysis rooted in grammatical considerations. However, it was my supposition that from the point of view of discursive behavior much could be observed. Where obvious, examples of certain potential translation universals (see CHESTERMAN 2010: 176-177), such as explicitation or interference, were noted. Tables were compiled of any 'anomalous'-seeming incidents or features, with similar events then being grouped together to examine relative frequency.

This being done, explanations were sought according to the following model described by CHESTERMAN:

If we ask why a translation profile has a given feature, we can first posit an initial cause - an explanation - in terms of the translation act: we find this feature, because of this decision, this translation strategy. If we then ask: why this decision, this strategy?, we can 
HANES, W. F. - Natural selections: regularities observed in a case of untrained ad hoc academic interpreting

appeal first to the translator's state of belief and knowledge, part of which is his/her knowledge of the relevant translation norms and his/ her attitude towards these norms. If we continue to ask why (why this belief, this attitude?), we have to go back further and look for causes in the sociocultural situation in which the translation was requested and carried out, including the norms themselves as social facts, plus such factors as the training and personal history of the translator, etc. (1998: 94)

\section{Results}

\subsection{General aspects of the event}

As mentioned above, the lecture was given in a smallish classroom to a fairly sparse audience. Due to the relatively low ceiling, the speaker stood stage right of the projection screen so as not to overlap the image, while the interpreter sat stage left behind a desk turned parallel to the opposing wall and slightly forward of the speaker, such that she faced the speaker (barred by the desk) and turned at the open edge of it to address the audience. Dress was semicasual, with little distinction between the speaker's, the interpreter's and the audience's attire, matching the level structure of the room.

The lecture was consecutively interpreted, i.e. short consecutively: one or two sentences interpreted at a time with no noticeable note-taking (DAM 2010:75). This approach, rather than simultaneous interpretation, was chosen for a number of possible reasons (some more obvious than others), not the least of which was the acoustics. Simultaneous speech reverberating around the small concrete room would probably have cancelled out both speakers. This condition was intensified by uncontrolled ambient circumstances, e.g. nobody bothered 
closing the door, which let in sporadic loud hallway chit-chat from one side, while the grounds crew passed by on the other with weed-eaters.

\subsection{Aspects of the Interpreter's performance}

As mentioned previously, discourse or behaviors apparently indicative of underlying assumptions in RL's interpreting performance were collected from the recording and have been organized below into a series of tables based on general categories.

Table 1.1. Some examples of added information (including explicitating and framing the discourse) during interpreted lecture at UFSC, November 2013. Portuguese dialog (boldface) is translated in brackets, with narration/ explanation in italics.

\begin{tabular}{|l|l|}
\hline \multicolumn{1}{|c|}{ time } & \multicolumn{1}{|c|}{ event } \\
\hline $3: 24$ & $\begin{array}{l}\text { RL: “...Camarões..." [Cameroon] and adds the aside } \\
\text { "um pais na Africa..." [a country in Africa] }\end{array}$ \\
\hline $23: 50$ & $\begin{array}{l}\text { RL: "o papel delas" [their role] } \\
\text { Explicitating the heading of a new topic, apparently } \\
\text { attempting to add structure to the lecture. }\end{array}$ \\
\hline $30: 15$ & $\begin{array}{l}\text { RL: "preparar para vestibular, digamos assim" } \\
\text { [to prepare for the college entrance exams, let's say] }\end{array}$ \\
\hline $32: 10-$ & $\begin{array}{l}\text { RL (to HJ): "Me permite uma rápida - dois minutos - } \\
\text { duas frases. Quando começou isto, ele começou com } \\
\text { a ideia de..." } \\
\text { [Allow me a quick - two minutes - two sentences. When } \\
\text { he began this, he began with the idea that...] } \\
\text { RL: "Agora ele vai..." [Now he's going to...] prefacing }\end{array}$ \\
\hline
\end{tabular}


HANES, W. F. - Natural selections: regularities observed in a case of untrained ad hoc academic interpreting

\begin{tabular}{|c|c|}
\hline & his speech before handing the floor back to $\mathrm{HJ}$ \\
\hline $33: 02$ & $\begin{array}{l}\text { RL: "que vocês podem ver ali" [which you can see } \\
\text { there] } \\
\text { Adding commentary not in original as far as I can tell, } \\
\text { guiding the audience "que é redondo, por isso chama } \\
\text { La Rotonde..." } \\
\text { [...which is round, that's why it's called the Rotunda...] }\end{array}$ \\
\hline $37: 18$ & $\begin{array}{l}\text { RL: “... deu o exemplo do projeto..." } \\
\text { [...he gave the example of a project...] } \\
\text { Rearranging information, referring to something } \\
\text { mentioned previously. }\end{array}$ \\
\hline $38: 45$ & $\begin{array}{l}\text { RL: “...radio web, que é extremamente forte...” } \\
\text { [...web radio, which is extremely strong...] } \\
\text { Parenthesis adding emotional emphasis. }\end{array}$ \\
\hline $\begin{array}{l}51: 37- \\
52: 16\end{array}$ & $\begin{array}{l}\text { RL: "Vou explicar um pouquinho o jogo de palavras } \\
\text { que eles fizeram..." } \\
\text { [I'm going to explain their wordplay a little...] } \\
\text { Stops } H J \text {, adds project background and explains pun in } \\
\text { its title. }\end{array}$ \\
\hline
\end{tabular}

Table 1.2. Examples of distancing the speaker during interpreted lecture at UFSC, November 2013. Portuguese dialog (boldface) is translated in brackets, with narration/ explanation in italics.

\begin{tabular}{|c|l|}
\hline time & \multicolumn{1}{|c|}{ event } \\
\hline $22: 44$ & $\begin{array}{l}\text { During a long stretch of text } \\
\text { RL (to HJ ): "uh huh" Indicating 'OK, I got all that } \\
\text { part; you can continue' (i.e., that his discourse was } \\
\text { directed to her rather than the audience). }\end{array}$ \\
\hline $26: 32$ & $\begin{array}{l}\text { RL: "Então, ele vai falar agora..." } \\
\text { [So now he's going to speak about...] }\end{array}$ \\
\hline
\end{tabular}


HANES, W. F. - Natural selections: regularities observed in a case of untrained ad hoc academic interpreting

\begin{tabular}{|l|l|}
\hline $28: 34$ & $\begin{array}{l}\text { RL: “Então, ele vai abordar a questão de..." } \\
\text { [So he's going to deal with the question of...] }\end{array}$ \\
\hline $30: 39$ & $\begin{array}{l}\text { RL: In response to a question from the audience for HJ } \\
\text { but directed to RL “...mas ele tá entendendo..." } \\
\text { [...but he understands...](i.e., '...Portuguese; you can } \\
\text { ask him directly') }\end{array}$ \\
\hline $37: 25$ & $\begin{array}{l}\text { A member of the audience interjects a question and } \\
\text { RL: (without missing a beat) “Isso". [That's right] } \\
\text { Speaker not consulted or allowed to answer for } \\
\text { himself. }\end{array}$ \\
\hline $56: 37$ & $\begin{array}{l}\text { RL: “Pra terminar, ele vai descrever..." } \\
{[\text { To conclude, he is going to describe...] }}\end{array}$ \\
\hline $1: 00: 20$ & $\begin{array}{l}\text { RL: “...que ele mencionou antes..." } \\
{[\ldots \text { which he mentioned before...] Didactic parenthesis }} \\
\text { reminding audience of a point HJ had previously made. }\end{array}$ \\
\hline
\end{tabular}

Table 1.3. Examples of lowering the register during an interpreted lecture at UFSC, November 2013. Portuguese dialog (boldface) is translated in brackets and narration/ explanation is in italics.

\begin{tabular}{|l|l|}
\hline \multicolumn{1}{|c|}{ time } & \multicolumn{1}{|c|}{ event } \\
\hline 23:05 & RL (to audience at the end of a sentence): “...né?" \\
(representative & [Literally: “Isn't it (so)?", similar to Right? or Eh?] \\
occasion) & $\begin{array}{l}\text { This exp ression is a common low-register } \\
\text { conversational filler whose function is to } \\
\text { solicit/ engender consensus with the listener }\end{array}$ \\
\hline
\end{tabular}

TradTerm, São Paulo, v. 23, Setembro/ 2014, p. 141-163 www. usp. br/tradterm http:// www. revistas. usp.br/tradterm/index 
HANES, W. F. - Natural selections: regularities observed in a case of untrained ad hoc academic interpreting

\begin{tabular}{|l|l|}
\hline 30:39 & $\begin{array}{l}\text { RL: “...mas ele tá entendendo..." } \\
\text { [...but he is understanding...] Rather than "Ele } \\
\text { entende"- he understands. The informality is } \\
\text { heightened by using 'tá', which is a low-register } \\
\text { abbreviation for the verb 'está'. }\end{array}$ \\
& Legend: RL = interpreter.
\end{tabular}

Table 1.4. Examples of the interpreter correcting the speaker/slideshow during interpreted lecture at UFSC, November 2013. Portuguese dialog (boldface) is translated in brackets, with narration/ explanation in italics.

\begin{tabular}{|l|l|}
\hline time & \multicolumn{1}{|c|}{ event } \\
\hline $13: 45$ & $\begin{array}{l}\text { RL replaces "vulgarização" [vulgarization] in the slide } \\
\text { with the more fitting and acceptable collocation } \\
\text { "difusão, popularização" [diffusion, popularization] }\end{array}$ \\
\hline $34: 23$ & $\begin{array}{l}\text { HJ (interrupting): "ANTIGUA"(which is Spanish) } \\
\text { RL (continuing): “...antiga. }\end{array}$ \\
\hline
\end{tabular}

Legend: $\mathrm{RL}=$ interpreter; $\mathrm{HJ}=$ lecturer.

Table 1.5. Examples of speaker-interpreter subdialog during interpreted lecture at UFSC, November 2013. Portuguese dialog (boldface) is translated in brackets, with narration/ explanation in italics.

\begin{tabular}{|l|l|}
\hline time & \multicolumn{1}{|c|}{ event } \\
\hline $3: 36$ & $\begin{array}{l}\text { During a memory lapse, RL asks for help by dragging } \\
\text { out syllable and raising her voice in a questioning tone. } \\
\text { HJ , understanding immediately, repeats the phrase } \\
\text { without being asked explicitly. }\end{array}$ \\
\hline $34: 23$ & $\begin{array}{l}\text { HJ : "petite camionnette"[small van] } \\
\text { RL: "camionetezinha que eles criaram..." [little bitty } \\
\text { pick-up/truck that they created...] } \\
\text { HJ (interrupting): "ANTIGUA" } \\
\text { RL (continuing): “... antiga. Bem antiga, bem bonita!" }\end{array}$ \\
\hline
\end{tabular}

TradTerm, São Paulo, v. 23, Setembro/2014, p. 141-163 www. usp. br/tradterm http:// www. revistas. usp.br/tradterm/index 
HANES, W. F. - Natural selections: regularities observed in a case of untrained ad hoc academic interpreting

\begin{tabular}{|l|l|}
\hline $48: 51$ & $\begin{array}{l}\text { RL: "ministério da...?"Again, slowing and raising pitch } \\
\text { to solicit repeated information. }\end{array}$ \\
\hline $50: 30$ & $\begin{array}{l}\text { RL stops to ask HJ for confirmation of something (in } \\
\text { French). } \\
\text { HJ : “No, no, no!" Sharply (or in panic) correcting RL's } \\
\text { misconception of a concept - his importance that the } \\
\text { exact idea must be portrayed. }\end{array}$ \\
\hline $55: 37$ & $\begin{array}{l}\text { RL: "Em dois mil e... (to HJ ) ...e..." [In (the year) two } \\
\text { thousand and... and..." } \\
\text { HJ: "2012."No explicit question asked. }\end{array}$ \\
\hline $56: 17$ & $\begin{array}{l}\text { HJ (correcting RL, adds): “En Brésil” } \\
\text { RL (adds): “Em Brasil” obediently, though no } \\
\text { translation is required. }\end{array}$ \\
\hline
\end{tabular}

\subsection{Aspects of the speaker's performance regarding interpretation}

As can be seen, especially in Table 1.5, not only was the interpreter quite visible, but an internal running dialog between speaker and interpreter was likewise visible. This dialog, in which the speaker demonstrated on several occasions that he was following the interpreter's discourse and even corrected her interpretation at times, was accompanied by certain bilingual overtures, which are described in Table 2 below. 
HANES, W. F. - Natural selections: regularities observed in a case of untrained ad hoc academic interpreting

Table 2. Bilingualism and target language overtures by the speaker during an event at UFSC (Florianópolis, SC, Brazil) in November 2013. Portuguese dialog (boldface) is translated in brackets, with narration/ explanation in italics.

\begin{tabular}{|c|c|}
\hline time & event \\
\hline $1: 31$ & $\begin{array}{l}\text { HJ appeared to be trying to speak in PT; seems to be } \\
\text { asking how to say "quimica" [chemistry] , takes } \\
\text { correction and immediately begins to use the PT } \\
\text { word; same thing for "logistique" [logistics]. Seems } \\
\text { obvious that he has some level of PT already, } \\
\text { attempting to (re)acquire using the interpreter. }\end{array}$ \\
\hline 28:00 & $\begin{array}{l}\text { HJ refers to a French project he undertook by the } \\
\text { translated title "Mão na Massa". }\end{array}$ \\
\hline 59:09 & $\begin{array}{l}\text { RL: “...rocha do....?" [... rock of...?] } \\
\text { HJ: "Sang" [Blood] } \\
\text { RL: “...Sangue, do vermelho sangue" [Blood, of red } \\
\text { blood] } \\
\text { Understands and is following interpretation to such a } \\
\text { degree that he supplies lacking information without } \\
\text { having to be asked explicitly. Answers RL in French, } \\
\text { not the audience in the target language. }\end{array}$ \\
\hline 1:04:30 & $\begin{array}{l}\text { HJ (in conclusion): “Muito obrigado." [Thank you } \\
\text { very much.] } \\
\text { Direct address in target language. }\end{array}$ \\
\hline
\end{tabular}

\section{Discussion}

Based on the multilevel explanatory model described by CHESTERMAN (1998: 94), which works backwards from features to strategies to norms, in this case 
regarding interpretation and the interpreter, the above-described groups of features will be narrowed into strategies and then norms.

\subsection{Interpreting strategies}

\subsubsection{High interpreter visibility}

Beginning from choices about the physical setup, especially the interpreter's positioning, there is a tendency toward high visibility. The interpreter's relatively closer position to the audience served to foreground her and, consequently, upstage (or marginalize) the speaker (see Figure 1). The setup closely resembled the image on the left (from BBC TV: MITCHELL 2014). In this arrangement, the speaker is well removed, framed - an 'image', while the interpreter is 'real'. Moreover, in this event, the interpreter was seated, in solidarity with the listeners, with a desk blocking off the speaker and open on the side to audience (such dynamics weigh heavily in an office/administrative context: i.e. the one behind the desk is the boss). Although such considerations could be ruled out as superficial and inconclusive, they had a cumulative effect when taken together with the other strategies.

Figure 1. Interpreter foregrounding/ backgrounding in contemporary media.

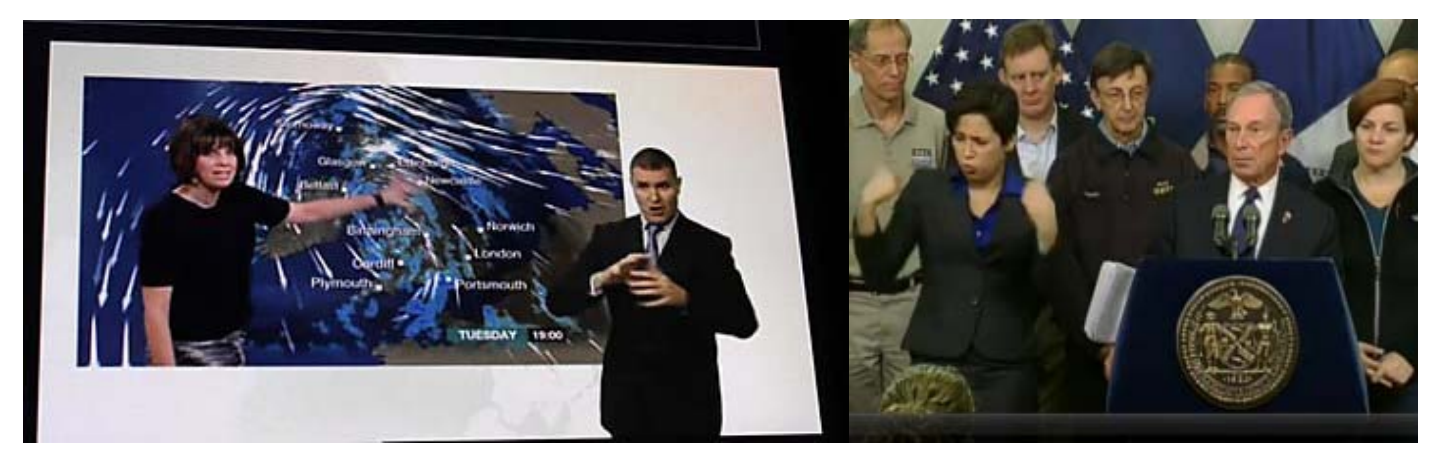

TradTerm, São Paulo, v. 23, Setembro/ 2014, p. 141-163

www. usp. br/tradterm

http:// www. revistas.usp.br/tradterm/index 
HANES, W. F. - Natural selections: regularities observed in a case of untrained ad hoc academic interpreting

\subsubsection{Distancing the speaker}

Referring to the speaker consistently in the third person rather than the first person, which would have made the interpreter transparent, served as a dialogic corollary to the physical positioning, reinforcing the backgrounding effect. A telling point was when the interpreter replied "uh-huh" to the speaker in mid-sentence (Table 1.2, 22:44), indicating that she believed the speech was directed to her, rather than the audience. Thus, to her, the lecture was a private conversation that she was relaying to the audience, as if she were talking to the speaker on the phone and then reporting the results to the audience. The speaker's direct connection with the audience (immediacy) was thus undercut. The speaker, in such an arrangement, becomes an "other", while the interpreter becomes "one of us". Moreover, without missing a beat, the interpreter directly fielded a question from the audience on at least one occasion (Table 1.2, 37:25), as if the question were for her and not the speaker.

\subsubsection{Correcting the speaker}

The speaker's verbal attempts at Portuguese, initially soliciting correction (see Table 2, 1:31), were consistently corrected by the interpreter, despite being intelligible to the audience (e.g. Table 1.5, 56:17). Likewise, a false cognate error ${ }^{5}$ in the PowerPoint was also corrected in passing verbally, although without any fanfare (Table 1.5, 13:45).

5 There were a number of inadequate collocations in the PowerPoint, which, as stated earlier, was not translated by the Interpreter. Although reluctant to digress and include any analysis of it in this paper, I nevertheless consulted a Brazilian translator (native speaker of Portuguese), who evaluated it as follows: "It was done in a haphazard way, and not revised or looked over." This further demonstrates the ad hoc quality of the event. 


\subsubsection{Explicitation: adding or customizing information}

Corrections to the speaker's deficiencies in target-language ability were expanded to include rhetorical framing (Table 1.1, 23:50), didactic parentheses (Table 1.2, 1:00:20), and cultural and factual explanations (Table 1.1, 38:45 \& 3:24, respectively), which implied deficiencies in these areas, i.e., the discourse was not seen as self-evident or self-explanatory.

\subsubsection{Appealing to the audience}

The interpretation strategy involved appeals to the audience on more than one level. Rhetorically, the use of "digamos assim" [let's say] (Table 1.1, 30:15) the first person plural, in which the "we" would imply the audience rather than the 'royal we' or the speaker, since it was used (on more than one occasion) to explain cultural concepts. This is a way of negotiating meaning with the audience, as was the use of the filler "né?" [right?/ ya know?] on a number of occasions at the end of phrases. These devices were accompanied by the use of Iow (i.e. casual conversation) register (e.g. Table 1.3, 30:39), which is a way of setting the audience at ease and saying 'I'm not better than you.'

\subsubsection{The co-creation of discourse}

Although, taken together, the preceding points could be read as the preexistence or generation of a certain degree of antipathy toward the speaker by the interpreter, the background relationship between the two completely confounds such a hypothesis, e.g. she was there as a volunteer, having been personally invited by the speaker, under whom she had studied, and was quite familiar with and sympathetic to the cause. Beside the general tone of their interchange, which could only be described as friendly, the running subdialog 
HANES, W. F. - Natural selections: regularities observed in a case of untrained ad hoc academic interpreting

with speaker described in Table 1.5, especially the witty repartee (more like talk show co-hosts) exemplified in Table 1.5, 34:23, also indicates a degree of collaboration or co-creation in the final product delivered to the audience. It was obvious that the speaker was closely following the interpretation due to the numerous occasions he immediately repeated the exact information necessary when the interpreter paused. The lively 'conference' described in Table 1.5 at $50: 30$ is also telling in that a bilateral consensus was sought about the direction of the Portuguese discourse.

\subsection{Norms deducible from these strategies}

The beliefs that led to the mentioned strategies are rooted in normative core values ("societal facts") about interpreting and the interpreter derived from larger societal systems. A few examples, or candidates for examples, are sketched below.

\subsubsection{An interpreter is an intermediary}

By intermediary, a visible, active and pivotal role between speaker and audience is meant, which was executed both literally (physically) and discursively, as described above. The interpreter was no 'fax machine'. Her pivotal role was reified as she assumed one position (facing the speaker) to receive information (antenna) and then another (facing the audience) to broadcast the results.

\subsubsection{The people's understanding is more important than formal or professional considerations}



ad hoc academic interpreting

Such urgency fits in with (or is a function of) the nature of this ad hoc situation/strata, which despite its ironic treatment in the title of the first section, represents very real socioeconomic spheres and constraints. Professional training, formal decorum (e.g. the preeminence of the speaker) and register (even in an academic setting) are secondary; people must understand, content must be adequated and brought 'down' to their level (even though the full audience had a secondary education). In this sense, the interpreter seems more like a social worker, which reveals the strong community interpreting traits in many aspects of the discourse/setting. Pursuant to this, the interpreter must 'interpret', and not 'orally translate' the discourse, i.e. connect the dots and guide the audience through the lecture, didactically reminding them of points made and structuring the discourse with prefaces.

\subsubsection{The interpreter is a negotiator}

The questions of power involved in the community-based approach outlined above place the interpreter in a no-man's land. Whereas in an international conference setting, where the speaker and audience are on equal footing (with the interpreter rather as a subaltern), the unequal distribution of knowledge and power (PÖCHHACKER 2013: 3) present in community-based interpretation settings forces the interpreter upon the horns of a dilemma: that of being a lackey or an antagonist to power. Ironically, the greater the power/knowledge disparity (alienation), the more pivotal (and creative) the interpreter's role becomes in the process. In the case presented in this article, we see a sort of formal antagonism to the speaker which goes unnoticed by both speaker and interpreter in their amicable running (semi-private) dialog. Such role conflict is also described by HARRIS AND SHERWOOD in the experience of bilingual youth thrust into practical interpreting tasks (1978: 158). This pressure was certainly increased by the ad hoc situation and the interpreter's inexperience, 
HANES, W. F. - Natural selections: regularities observed in a case of untrained ad hoc academic interpreting

such that she exclaimed in exasperation when interviewed later "That's the last time I will mess with your field!"

\subsubsection{The interpreter's power means the people's weakness}

Although in this case, the interpreter's posture would appear to have been antagonistic toward the speaker, there is another side to the community-based interpreting coin introduced in 4.2.2, i.e. the stronger the interpreter's position, the more incapable people are considered. Thus, it is not exactly the discourse that is deficient and wanting explanation, but rather (the fear of) the audience's inability to grasp the content that motivates the interpreter. This is demonstrable from the point of view of Brazilian society, which is a culture of intermediaries: pumping your own gas is still strictly prohibited; most banks provide specific personnel to (ironically) shepherd people through automatic teller processes; only recently in many retail sectors have products become widely available on shelves, i.e. a gatekeeper (salesman/clerk) must be negotiated with, who then retrieves the item from stock; there is a whole nationwide industry of proxy couriers who stand in line to retrieve documents from the department of motor vehicles (which should in itself be sufficient to indicate the level of bureaucracy). All this going on in a cozy classroom where everybody was literally on the same level and dressed pretty much alike.

\subsubsection{The intercultural communicator must be open}

The speaker's discourse revealed a need to (a) validate the target culture by speaking a little in the target language and employing culturally relevant examples (he used the lyrics from a Chico Buarque song to demonstrate how science could be effectively popularized); (b) take care that his ideas were being 
HANES, W. F. - Natural selections: regularities observed in a case of untrained ad hoc academic interpreting

clearly communicated in the target language by monitoring (policing) the interpretation, although not to the point of interfering in the interpreter's explanatory asides, requested or not; (c) remain an open, accessible channel of communication. After all, his field is the popularization of science, which is a domestic species of intercultural communication.

\section{Conclusions, limitations, applicability}

\section{1 Limitations and applicability}

Since the event was only subsequently considered with respect to interpreting, a video recording was not performed. In the same way that, socially, the communication was more than just the action of the interpreter, the interaction was also more complex than what occurred in the audio channel alone. Thus lack of video, lamentably, removes visual evidence of cues, positioning and expression through body language. However, its absence does conveniently help preserve the anonymity of the principal actors and, from an anthropological point of view, an intrusive tripod may have interfered with the naturalness of the proceedings. Interviewing members of the audience regarding reception might also have contributed valuable information. As a nonlongitudinal case study - a single brief event - it is recognized that any extrapolations from the data are naturally on shaky ground, empirically speaking, and follow-up study with a broader sample is necessary for some degree of statistical validity or any ambitions regarding training, practice or policy. 
HANES, W. F. - Natural selections: regularities observed in a case of untrained ad hoc academic interpreting

\section{2 General conclusions}

That being said, the norms or principles derived obliquely from the features of the interpreting discourse are interesting and warrant further investigation, namely: in the ad hoc (read: community) milieu, the interpreter is a visible, active intermediary; the strength of the interpreter's role, especially as a negotiator, is a function of the inequality locally present in the enveloping polysystem; the dissemination of ad hoc interpretation could be seen as a function of marginalizing socioeconomic forces and, to the chagrin of some, may actually be the natural state of interpretation.

\section{Acknowledgements}

This study was supported by CAPES. Sincere thanks to RL for her input and openness, as well as to Vanessa Hanes for Portuguese language consultation.

\section{References}

Chesterman, A. Translation universals. In: Gambier, Y.; van Doorslaer, L. Handbook of Translation Studies. Vol. 2. Amsterdam/Philadelphia: Benjamins Publishing Company, 2011. p. 175-179.

.Description, Explanation, Prediction: A Response to Gideon Toury and Theo Hermans. Current Issues in Language \& Society, vol. 5, n. 1\&2, 1998. p. 9198.

. From 'Is' to 'Ought': Laws, Norms and Strategies in Translation Studies.

Target, vol. 5, n. 1, 1993. p. 1-20. 
HANES, W. F. - Natural selections: regularities observed in a case of untrained ad hoc academic interpreting

Dam, H. Consecutive interpreting. In: Gambier, Y.; VAn Doorslaer, L. Handbook of Translation Studies. Vol.1. Amsterdam/ Philadel phia: Benjamins, 2010. p. 75-79.

Deaf Reality Series: A series within Deaf community around the world. Mayor Bloomberg's Sign Language Interpreter @ News Conference in Regards to Hurricane Sandy. Monday, October 29, 2012. Available at: «ttp:// deafrealityseries. blogspot. be/2012 1001 archive. html>. (1 May 2014).

Gany, F. et al. The impact of medical interpretation method on time and errors. J ournal of General Internal Medicine, vol. 22, n. 2, 2007. p. 319-323.

GILE, D. Consecutive vs. Simultaneous: Which is more accurate?. Interpretation Studies, n. 1, dez. 2001. p. 8-20.

Harris, B.; Sherwood, B. Translating as an Innate Skill. In: Gerver, D.; Sinaiko, H. Language, Interpretation and Communication. New York: Plenum Press, 1978. p. 155-170.

KLEINERT, C. Formación de intérpretes en náhuatl, totonaco, otomí, mazateco y popoloca: una experiencia para la justicia. In: PeRAlta, K. et al. Quinto congreso internacional de traducción y interpretación. Traduciendo Culturas: más que un desafío. Universidad Autónoma de Baja California, 2012. p. 137-145.

Intérpretes sociales en el ámbito de la justicia. Actualizaciones en Comunicación Social. Santiago de Cuba: Centro de Linguística Aplicada, 2013. p. 529-533.

Lambert, J.; Illescu, C. (Eds.). Universe-cities as Problematic Global Villages: Continuities and Shifts in our Academic Worlds. Florianópolis: EdUFSC, 2014.

Martinsen, B. PSI: Challenges and how to meet them. In: Garzone, G.; ViezZI, M. Interpreting in the 21st Century. Amsterdam/Philadelphia: John Benjamins, 2002. p. 257-267.

MITCHeLL, A. A day in the life of a BSL Interpreter for BBC News. About the BBC Blog. Available at: বhttp:// www. bbc.co.uk/ blogs/aboutthebbc/ posts/A-day-inthe-life-of-a-BSL-Interpreter-for-BBC-News>. (29 J an 2014). 
HANES, W. F. - Natural selections: regularities observed in a case of untrained ad hoc academic interpreting

PIEKKARI, R. et al. Translation behaviour: An exploratory study within a service multinational. International Business Review, v.22, n. 5, 2013. p. 771-783.

PöCHHACKER, F. Interpreting. In: GAMBIER, Y.; VAN DOORSLAER, L. Handbook of Translation Studies.Vol.1. Amsterdam/Philadelphia: Benjamins, 2010. p. 153158.

PöCHHACKER, F.; SHLESINGER, M. (Eds.). Healthcare Interpreting: Discourse and Interaction. Amsterdam/ Philadelphia: Benjamins, 2007.

PyM, A. The translator as non-author, and I am sorry about that. 2010. Available at: $\quad$ http:// usuaris.tinet. cat/ apym/ online/translation/ 2010 translatore as author.pdf. $>$. (2 Feb 2012).

SHLESINGER, M. Making the most of settling for less. Forum - J ournal of Translation Studies, vol. 5, n. 2, 2007. p.147-170. - Healthcare interpreting: Legal requirement, necessary evil, or best practice?. In: EPSTEIN. L. Culturally Appropriate Health Care by Culturally Competent Health Professionals: Inter-national Workshop Report. Ramat-Gan: The Israel National Institute for Health Policy and Health Services, 2008. p. 7184.

TourY, G. Descriptive Translation Studies and Beyond. Amsterdam and Philadelphia: Benjamins, 1995. - Monitoring discourse transfer: a test-case for a developmental model of translation. In: HOUSE, J.; BLUM-KULKA, S. Interlingual and Intercultural Communication: Discourse and Cognition in Translation and Second Language Acquisition Studies. Tubingen: Narr, 1986. p. 79-94.

Woloshin, S.et al. Language Barriers in Medicine in the United States. JAMA, vol.273,

n.

9 , 1995. p.

$724-728$. 